\title{
Effect of pH Cycling and Zinc Ions on Calcium and Magnesium Carbonate Formation in Saline Fluids at Low Temperature
}

\author{
Veerle Vandeginste
}

check for

updates

Citation: Vandeginste, V. Effect of pH Cycling and Zinc Ions on Calcium and Magnesium Carbonate

Formation in Saline Fluids at Low Temperature. Minerals 2021, 11, 723 https://doi.org/10.3390/ $\min 11070723$

Academic Editors: Carlos M. Pina and Carlos Pimentel

Received: 3 June 2021

Accepted: 2 July 2021

Published: 5 July 2021

Publisher's Note: MDPI stays neutral with regard to jurisdictional claims in published maps and institutional affiliations.

Copyright: (C) 2021 by the author. Licensee MDPI, Basel, Switzerland. This article is an open access article distributed under the terms and conditions of the Creative Commons Attribution (CC BY) license (https:// creativecommons.org/licenses/by/ $4.0 /)$.
Department of Materials Engineering, Campus Bruges, KU Leuven, 8200 Bruges, Belgium; veerle.vandeginste@kuleuven.be

\begin{abstract}
The formation of dolomite is very challenging in the laboratory under ambient conditions due to kinetic inhibition. The goal of this study was to test the impact of $\mathrm{pH}$ cycling and zinc ions on the formation of magnesium-rich carbonates in saline fluids at a low temperature. Batch reactor experiments were conducted in two series of $\mathrm{pH}$ cycling experiments, one without and one with zinc ions, at $43{ }^{\circ} \mathrm{C}$. The results after 36 diel $\mathrm{pH}$ cycles indicate a reaction product assemblage of hydromagnesite, aragonite and magnesite in the experiments without zinc ions, and of magnesite and minor aragonite in the experiments with zinc ions. The presence of zinc ions leads to a decrease in the $\mathrm{pH}$ in the acid phase of the cycling experiments, which likely plays a role in the reaction product assemblage. Moreover, the hydration enthalpy and other specific ion effects could be additional factors in the formation of magnesium-rich carbonate. The results show a clear evolution towards increasing incorporation of magnesium in the carbonate phase with cycle number, especially in the experiments with zinc ions, reflecting a ripening process that is enhanced by $\mathrm{pH}$ cycling. Hence, repeated $\mathrm{pH}$ cycling did not lead to more ordered dolomite (from protodolomite), but rather to the

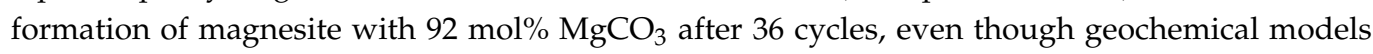
indicate a higher saturation index for dolomite than for magnesite.
\end{abstract}

Keywords: dolomite; magnesite; hydromagnesite; $\mathrm{pH}$ cycles; lagoon; hypersaline

\section{Introduction}

The formation of dolomite (calcium magnesium carbonate) has fascinated many researchers worldwide because of the so-called "dolomite problem", referring to the abundant presence of dolomite in ancient sedimentary systems in contrast to its rare occurrence in recent systems and the difficulty in forming abiotic dolomite in the laboratory under ambient temperature and pressure [1,2]. Despite the fact that seawater is oversaturated with respect to dolomite, the latter does not precipitate due to kinetic inhibition at a low temperature [3]. Magnesite (magnesium carbonate) forms also quite slowly in laboratory conditions at ambient pressure and temperature [4]. At low temperature, hydrated magnesium carbonates are rather formed, such as hydromagnesite $\left[\mathrm{Mg}_{5}\left(\mathrm{CO}_{3}\right)_{4}(\mathrm{OH})_{2} \cdot 4 \mathrm{H}_{2} \mathrm{O}\right]$, dypingite $\left[\mathrm{Mg}_{5}\left(\mathrm{CO}_{3}\right)_{4}(\mathrm{OH})_{2} \cdot x \mathrm{H}_{2} \mathrm{O}\right]$, lansfordite $\left[\mathrm{MgCO}_{3} \cdot 5 \mathrm{H}_{2} \mathrm{O}\right]$ and nesquehonite $\left[\mathrm{MgCO}_{3} \cdot 3 \mathrm{H}_{2} \mathrm{O}\right]$ [5]. It is generally thought that one of the underlying factors for inhibition of the incorporation of magnesium into the crystal structure is the hydration shell of the magnesium cation [6]. The hydration enthalpy of magnesium cations $\left(-1921 \mathrm{~kJ} \cdot \mathrm{mol}^{-1}\right)$ is stronger than that of calcium cations $\left(-1577 \mathrm{~kJ} \cdot \mathrm{mol}^{-1}\right)$. It was shown that the addition of zinc ions, which have a stronger hydration enthalpy $\left(-2046 \mathrm{~kJ} \cdot \mathrm{mol}^{-1}\right)$ than magnesium ions, can accelerate dolomitization in saline fluids at a high temperature [7]. Besides the slow dehydration of magnesium ions, experiments in water-free environments indicate an additional entropic inhibition preventing the formation of longrange ordered crystallographic structures at ambient conditions [8]. Furthermore, results of the synthesis of double carbonates with dolomite-like structures suggest that the shape and relative size of coordination polyhedra of the involved cations impact the kinetics of the for- 
mation of those minerals [9]. A few studies that claim successful formation of dolomite or magnesite at low temperature made use of carboxylated polystyrene microspheres $[10,11]$.

Dolomite is often associated with hypersaline and alkaline lakes and lagoons in recent sedimentary environments and microbial mediation [12,13]. In such natural environments, geochemical conditions show variations, generally in a cyclic manner. For example, seawater $\mathrm{pH}$ varies over different timescales, and shows interdecadal cycles derived from reef data, interannual cycles derived from open ocean data, and diel (24-h) cycles derived from data from shallow coastal areas [14]. Moreover, in natural systems of hard water lakes, the cycling of calcium and carbonate species is an important seasonal process driven by the biogenic formation of calcite alternating with the dissolution of calcite due to aerobic decomposition of organic matter [15]. Previous research showed that dissolution-precipitation cycles could lead to the increasing formation of stable over metastable phases, following Ostwald's rule [16]. Cycling of $\mathrm{pH}$ and temperature showed the formation of dolomite at around $40^{\circ} \mathrm{C}$ in experiments by Liebermann [17] and Deelman [16], but magnesite was the reaction product in a similar study by dos Anjos et al. [18].

Here, the goal of our study is to test the effect of $\mathrm{pH}$ cycling and zinc ions on the formation of calcium and magnesium carbonates in saline fluids at a low temperature over a period of five weeks of consecutive diel cycles. The evolution of the type and relative abundance of reaction products with the number of cycles is determined. The results from the $\mathrm{pH}$ cycling experiments with and without zinc ions are compared.

\section{Materials and Methods}

\subsection{Materials and Batch Reactor Experiments}

The experimental procedure is inspired by the one developed by Liebermann [17] and Deelman [16] with $\mathrm{pH}$ cycling, but without temperature cycling. Two series of experiments were set up, each conducted in triplicate, with the second series testing the additional effect of the presence of zinc ions. The experiments were run over a total of 37 consecutive days with diel $\mathrm{pH}$ cycles. The fluids have a composition with a salinity of six times that of seawater, and the temperature was thermostatically controlled at $43^{\circ} \mathrm{C}$ for the entire duration of the experiments. The temperature was selected based on the experimental conditions used by Liebermann [17], reflecting a high-end temperature of evaporative lagoons in warm regions. The $\mathrm{pH}$ cycles consisted of $1 \mathrm{~h}$ acid phase and $23 \mathrm{~h}$ base phase. The acidity was adapted by the addition of $1.2 \mathrm{~mL} 3.0 \mathrm{~mol} \cdot \mathrm{L}^{-1} \mathrm{HCl}$ for the acid phase and $2 \mathrm{~mL} 1.0 \mathrm{~mol} \cdot \mathrm{L}^{-1} \mathrm{Na}_{2} \mathrm{CO}_{3}$ for the base phase. Despite the addition of $3.2 \mathrm{~mL}$ fluid to adapt the $\mathrm{pH}$ of the solutions in each cycle, the total weight of the fluids remained within a fluctuation of less than $10 \mathrm{~g}$ over the entire 37-day long experiment. This was achieved by taking a $1 \mathrm{~mL}$ fluid sample each day just before the acid phase and by not completely sealing the reactors and thus allowing some evaporation. Still, the addition of chemicals to simulate the $\mathrm{pH}$ cycles leads to a slight increase in alkalinity and salinity of the solutions with each cycle, which could potentially influence the transformation of carbonate minerals. Nevertheless, the $\mathrm{pH}$ cycling conditions are the same in the two series, with and without zinc ions, and the difference in results can thus be compared to establish the effect of zinc.

The fluids for the first series of experiments contained milliQ water (Merck Millipore, Burlington, VT, USA) with $2.831 \mathrm{~mol} \cdot \mathrm{L}^{-1} \mathrm{NaCl}, 0.097 \mathrm{~mol} \cdot \mathrm{L}^{-1} \mathrm{MgCl}_{2}, 0.055 \mathrm{~mol} \cdot \mathrm{L}^{-1}$ $\mathrm{MgSO}_{4} \cdot 7 \mathrm{H}_{2} \mathrm{O}$ and $0.062 \mathrm{~mol} \cdot \mathrm{L}^{-1} \mathrm{KCl}$. For the second series, $0.030 \mathrm{~mol} \cdot \mathrm{L}^{-1} \mathrm{ZnCl}_{2}$ was added to this composition and the concentration of $\mathrm{NaCl}$ was slightly decreased to $2.740 \mathrm{~mol} \cdot \mathrm{L}^{-1} \mathrm{NaCl}$ to keep the ionic strength the same as in the first series. Testing the potential effect of zinc ions was inspired by the work of Vandeginste et al. [7] on dolomitization at a high temperature. A total of $65 \mathrm{~mL}$ solution was used for each experiment. The fluids were transferred in reactors, placed on temperature-controlled hotplate stirrers, and reacted with $306 \mathrm{mg} \mathrm{CaCO}_{3}$ at a temperature of $43^{\circ} \mathrm{C}$. The starting $\mathrm{pH}$ was 8.6 for the first series and 6.4 for the second series (with zinc ions). Subsequently, the $\mathrm{pH}$ cycled between 6.5-7.0 for the acid phase and 7.9-8.3 for the base phase in the first series, and between 5.7-6.1 for the acid phase and 7.9-8.4 for the base phase in the second series. The fluids 
were continuously stirred during the experiments. Before the acid phase of each cycle, a $1 \mathrm{~mL}$ fluid sample was taken, washed with milliQ water to dissolve potential halite in the reactions solids, centrifuged and dried in an oven at $50{ }^{\circ} \mathrm{C}$. The powder samples were then characterized using powder X-ray diffraction analysis.

\subsection{Characterization}

For X-ray diffraction analysis, the powder samples distributed on zero background silicon holders were scanned over a sampling range of ( 2.5 or) 5 to $70^{\circ} 2 \theta$ with a step size of 0.0066 and a scan speed of $0.023^{\circ} 2 \theta$ per second on a PANalytical $X^{\prime}$ Pert Pro (Malvern PANalytical, Malvern, UK) with $\mathrm{CuK} \alpha$ radiation at $40 \mathrm{kV}$ and $40 \mathrm{~mA}$. Mineralogical identification was conducted by comparison with published mineral reference patterns. Rietveld refinement was used for quantification of the identified minerals using Profex software [19].

\subsection{Geochemical Modeling}

Geochemical equilibrium reactions and saturation index of minerals were calculated using PHREEQC (version 3, USGS, Reston, VA, USA) [20] with the Pitzer database [21]. The composition of the starting fluids was used along with the measured $\mathrm{pH}$ and a temperature of $43^{\circ} \mathrm{C}$. Then, the fluid was reacted with calcite to simulate the addition of calcite powder at the start of the experiment. The $\mathrm{pH}$ and saturation index was calculated from this solution. Subsequently, the addition of $1.2 \mathrm{~mL} 3.0 \mathrm{~mol} \cdot \mathrm{L}^{-1} \mathrm{HCl}$ was modeled to calculate the geochemical equilibrium reactions and saturation index of minerals, and then also the addition of $2.0 \mathrm{~mL} 1.0 \mathrm{~mol} \cdot \mathrm{L}^{-1} \mathrm{Na}_{2} \mathrm{CO}_{3}$ base. The calculations were conducted for equilibrium reactions, and no kinetic constraints or experimental durations were considered in the geochemical modeling.

\section{Results}

\subsection{Effect of $p H$ Cycling}

In the control experiments, the starting fluid $\mathrm{pH}$ was 8.6 , and the $\mathrm{pH}$ cycling was conducted through repeated addition of $\mathrm{HCl}$ for the acid phase with a $\mathrm{pH}$ of 6.5-7.0 and $\mathrm{Na}_{2} \mathrm{CO}_{3}$ for the base phase with a $\mathrm{pH}$ of 7.9-8.3. After one diel cycle, part of the starting calcite dissolved, and high magnesium calcite formed with a $d_{104}$ spacing of $2.960 \pm 0.006 \AA$ (Figure 1). Based on Hobbs and Xu [22] correlation between $d_{104}$ and mol\% $\mathrm{MgCO}_{3}$ (referring to bulk magnesium concentration in the carbonate), this measured $d$ spacing suggests about $25 \mathrm{~mol}_{\%} \mathrm{MgCO}_{3}$ in the disordered carbonate structure with the magnesium content. After the second cycle, the calcite content decreased further, more high magnesium calcite formed with a $d_{104}$ spacing of $2.948 \pm 0.002 \AA$ (about $30 \mathrm{~mol} \% \mathrm{MgCO}_{3}$ ), and also some aragonite formed. After five diel cycles, all calcite had disappeared, more aragonite formed, and very high magnesium calcite (also called protodolomite) formed with a $d_{104}$ spacing of $2.91 \pm 0.01 \AA$ (about $42 \mathrm{~mol} \% \mathrm{MgCO}_{3}$ ).

In the subsequent four weeks of diel $\mathrm{pH}$ cycles, aragonite remained part of the reaction products, and also hydromagnesite $\left[\mathrm{Mg}_{5}\left(\mathrm{CO}_{3}\right)_{4}(\mathrm{OH})_{2} \cdot 4 \mathrm{H}_{2} \mathrm{O}\right]$ formed (Figure 2). The composition of magnesium carbonate shifted from very high magnesium calcite (protodolomite) towards magnesite composition with a $d_{104}$ spacing of $2.774 \pm 0.007 \AA$ (about $90 \mathrm{~mol} \%$ $\mathrm{MgCO}_{3}$ ) between three and four weeks of diel cycles. At the end of the experiments, after 36 diel cycles, the reaction product consisted of $17 \% \pm 5 \%$ aragonite, $55 \% \pm 16 \%$ hydromagnesite and $28 \% \pm 11 \%$ magnesite (Figure 3 ). The evolution of relative abundances of different minerals versus cycle number is presented in Figure 4, and the evolution of the shift in $d$ value of the main peak of high magnesium calcite or magnesite phase is presented in Figure 5. 


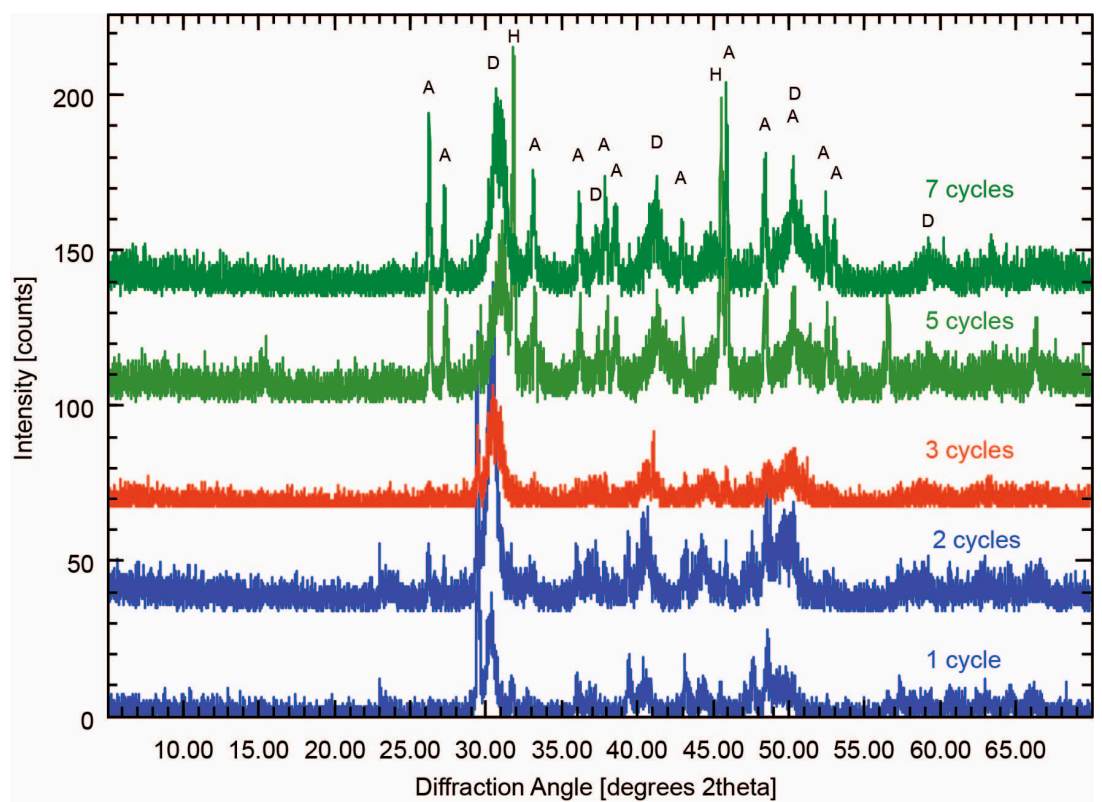

Figure 1. Powder X-ray diffractograms of reaction solids after 1, 2, 3, 5 and 7 diel cycles (each indicated by a different colour) in the first (control) series of $\mathrm{pH}$ cycling experiments. The original calcite disappears and instead aragonite (A) and (very) high magnesium calcite (D) forms with a gradual shift towards higher $\mathrm{Mg}$ incorporation. Some undissolved halite $(\mathrm{H})$ is also identified.

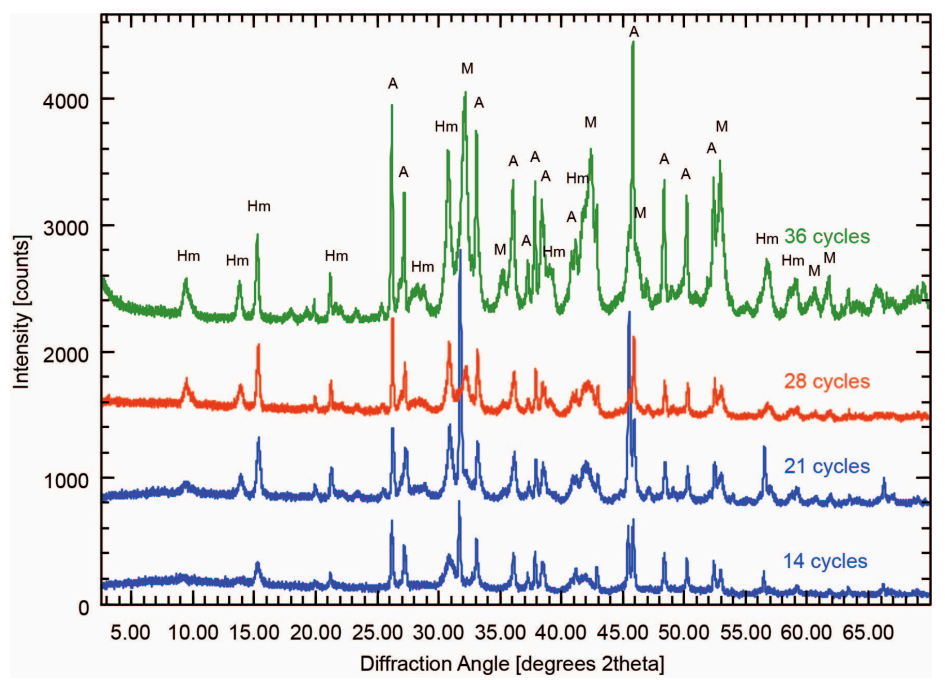

Figure 2. Powder X-ray diffractograms of reaction solids after 14, 21, 28 and 36 diel cycles (each indicated by a different colour) in the first (control) series of $\mathrm{pH}$ cycling experiments. The composition changes from aragonite and very high magnesium calcite to aragonite (A), magnesite (M) and hydromagnesite $(\mathrm{Hm})$. 


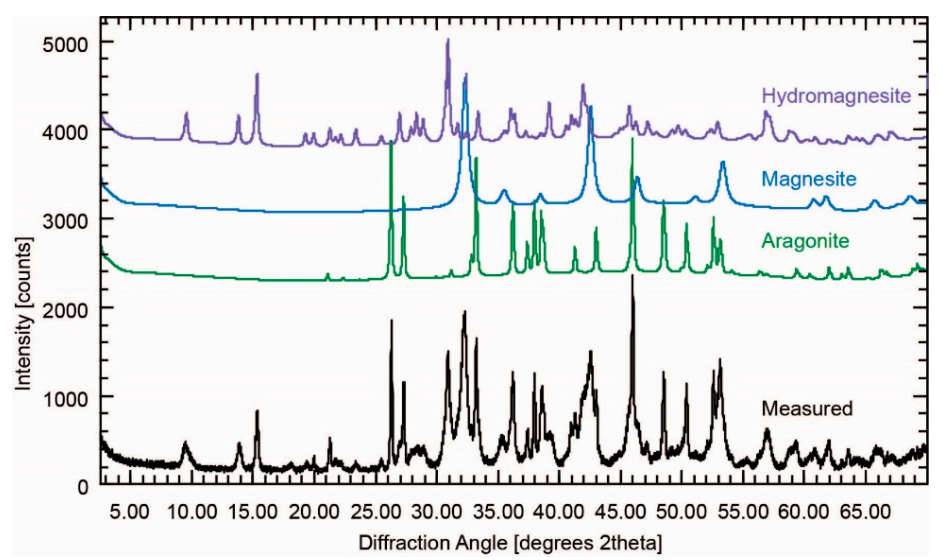

Figure 3. Powder X-ray diffractogram of the reaction product after 36 cycles at the end of the experiment in the first (control) series of $\mathrm{pH}$ cycling experiments, with the Rietveld refined fit for aragonite, magnesite and hydromagnesite (each indicated by a different colour) used for quantification of the relative mineral contents.

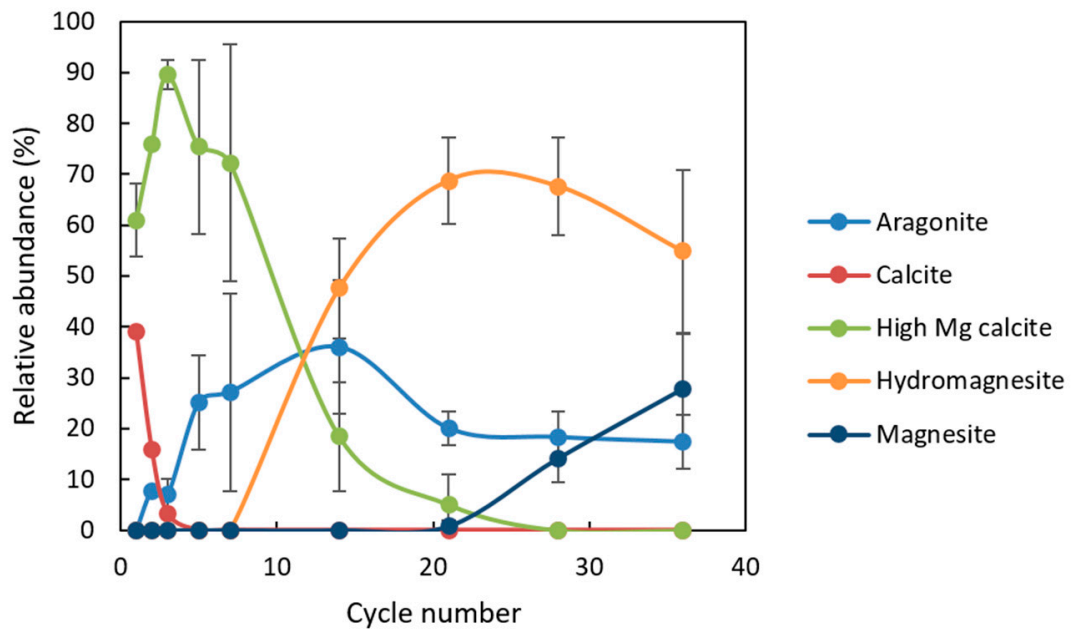

Figure 4. Plot presenting the evolution of the relative abundance of minerals in the reaction products versus cycle number for the first (control) series of $\mathrm{pH}$ cycling experiments. The quantification is based on Rietveld analysis of X-ray diffraction data. The error bars (in light grey) reflect the standard deviation of the results from the triplicate experiments.

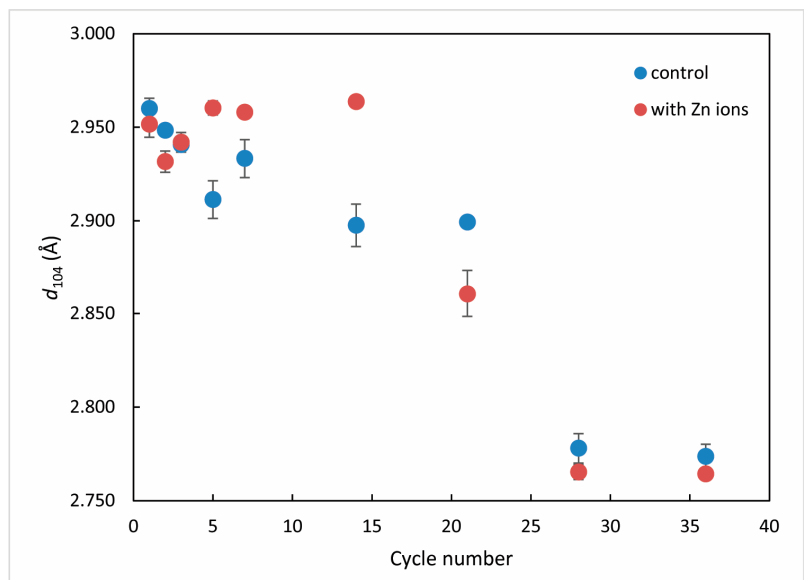

Figure 5. Plot of $d_{104}$ spacing of the (very) high magnesium calcite or magnesite phase versus cycle 
number. The data are presented for both the first (control) series and the second (with zinc ions) series of $\mathrm{pH}$ cycling experiments. The error bars (in light grey) are based on the standard deviation of triplicate experiments.

\subsection{Combined Effect of $p H$ Cycling and Zinc Ions}

For the experiments with added zinc ions, the $\mathrm{pH}$ conditions were slightly different than those in the first series without zinc ions. The addition of $\mathrm{ZnCl}_{2}$, a Lewis acid, leads to a decrease in the fluid starting $\mathrm{pH}$ to 6.4. Subsequently, the diel cycles had an acid phase with a $\mathrm{pH}$ of 5.7-6.1 and a base phase with a $\mathrm{pH}$ of 7.9-8.4. After one diel cycle, part of the calcite dissolved, hydrozincite formed as well as a small amount of aragonite and magnesium calcite with a $d_{104}$ spacing of $2.952 \pm 0.007 \AA$ (about 28 mol\% $\mathrm{MgCO}_{3}$ ). With the second and third cycles, the calcite content decreased further, the aragonite content increased slightly, the hydrozincite content decreased and the amount of high magnesium calcite increased substantially (Figure 6). The high magnesium calcite after the third cycle had a $d_{104}$ spacing of $2.942 \pm 0.005 \AA$ (about 31 mol\% $\mathrm{MgCO}_{3}$ ). After the fifth cycle, the reaction product consisted mainly of high magnesium calcite and also some huntite $\left[\mathrm{CaMg}_{3}\left(\mathrm{CO}_{3}\right)_{4}\right]$ started to form.

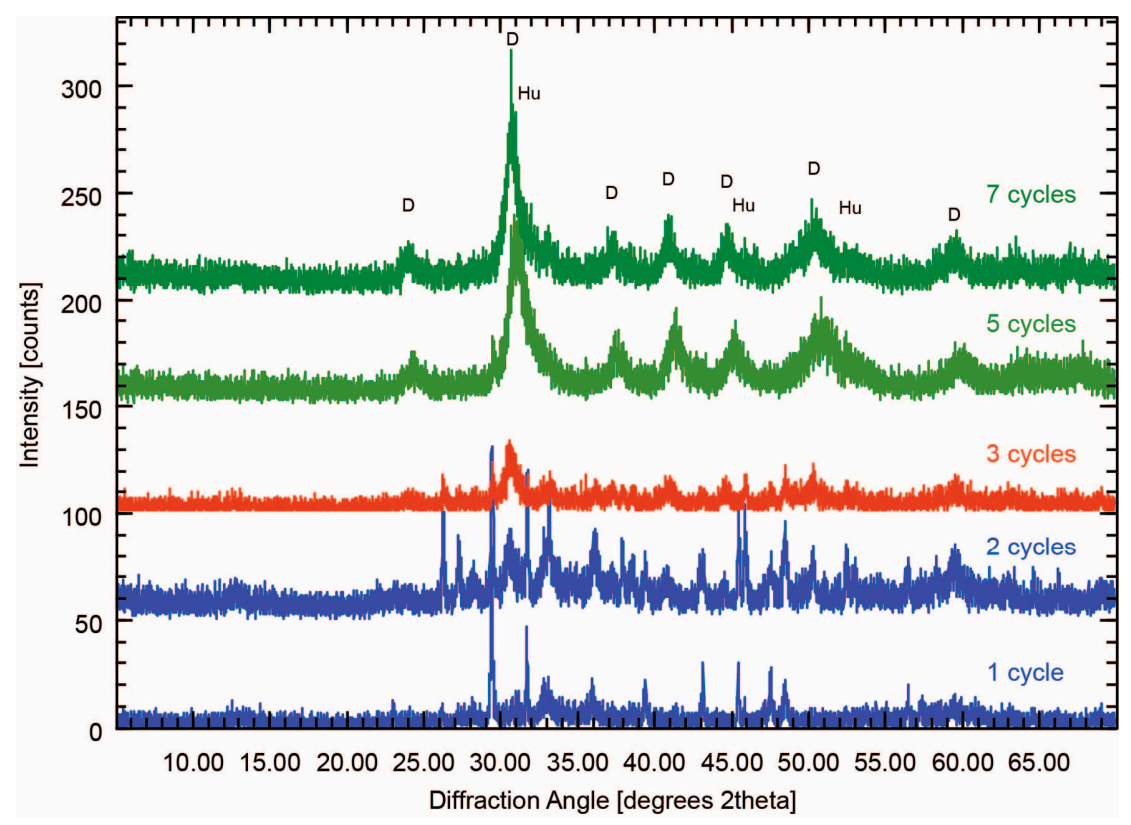

Figure 6. Powder X-ray diffractograms of reaction solids after 1, 2, 3, 5 and 7 diel cycles (each indicated by a different colour) in the second series of $\mathrm{pH}$ cycling experiments, which contain zinc ions. First, some original calcite dissolves and aragonite, hydrozincite and high magnesium calcite form. Subsequently, the reaction product is high magnesium calcite (D) and huntite (Hu).

After four weeks of diel $\mathrm{pH}$ cycles, the composition of magnesium carbonate and huntite shifted to magnesite with a $d_{104}$ spacing of $2.764 \pm 0.002 \AA$ (about $92 \mathrm{~mol} \% \mathrm{MgCO}_{3}$ ) (Figures 5 and 7). At the end of the experiments, after 36 diel cycles, the reaction product consisted of $97.3 \% \pm 0.3 \%$ magnesite and $2.7 \% \pm 0.3 \%$ aragonite (Figure 8 ). The evolution in the relative abundance of minerals in the reaction product assemblage versus cycle number is presented in Figure 9. 


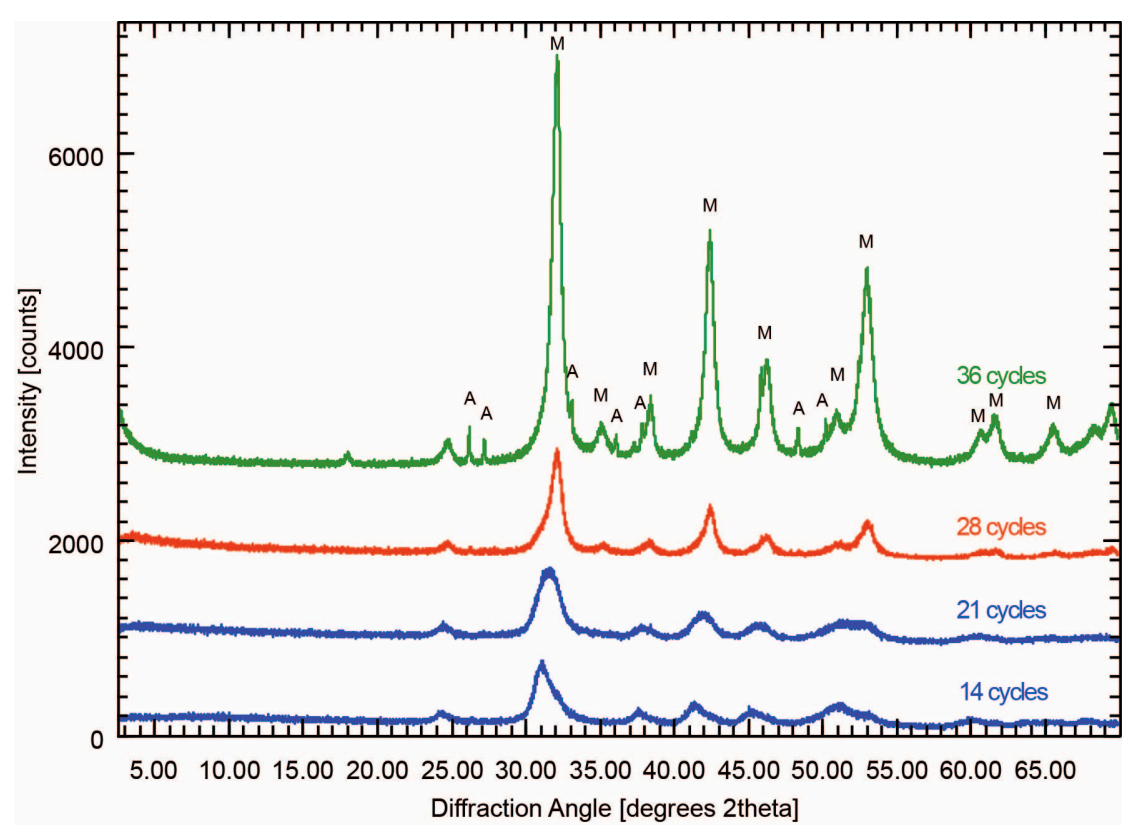

Figure 7. Powder X-ray diffractograms of reaction solids after 14, 21, 28 and 36 diel cycles (each indicated by a different colour) in the second series of $\mathrm{pH}$ cycling experiments, which contain zinc ions. The composition changes gradually from high magnesium calcite and huntite to magnesite (M) and minor aragonite (A).

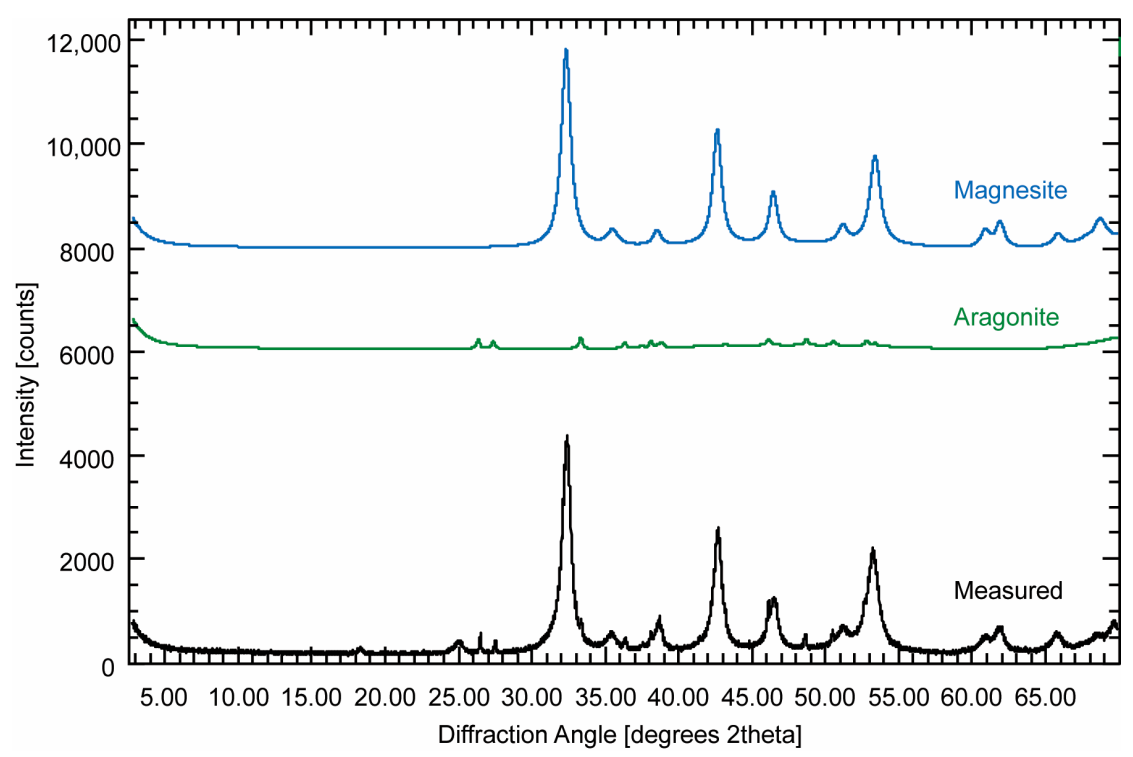

Figure 8. Powder X-ray diffractogram of the reaction product after 36 cycles at the end of the experiment for the second (with zinc ions) series of $\mathrm{pH}$ cycling experiments, with the Rietveld refined fit for aragonite and magnesite (each indicated by a different colour) used for quantification of the relative mineral contents. 


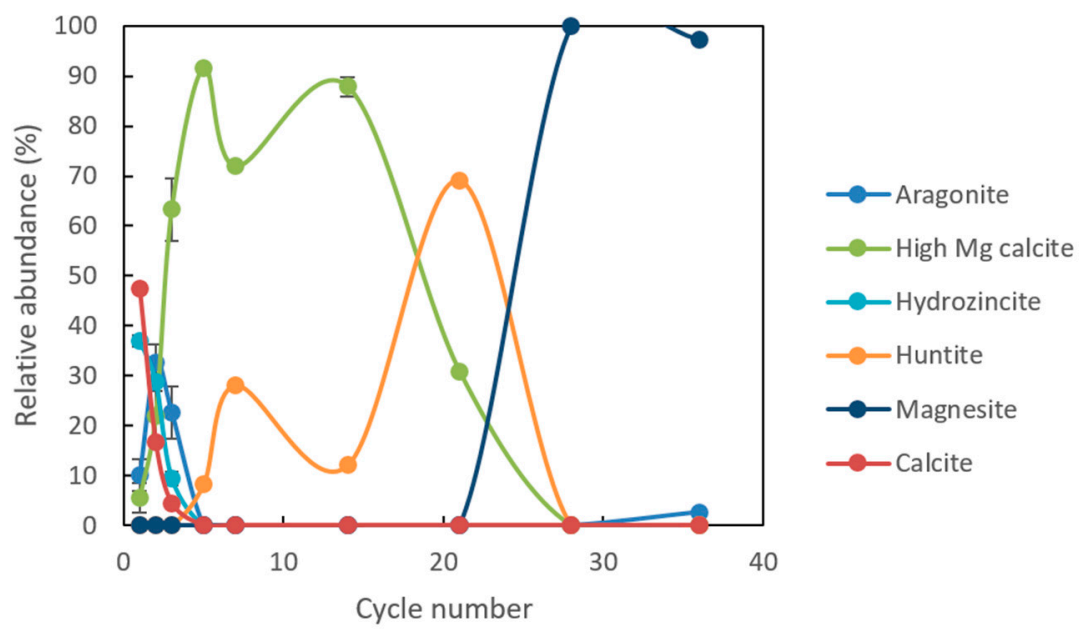

Figure 9. Plot presenting the evolution of the relative abundance of minerals in the reaction products versus cycle number for the second series of $\mathrm{pH}$ cycling experiments (with zinc ions). The quantification is based on Rietveld analysis of X-ray diffraction data. The error bars (in light grey) reflect the standard deviation of the results from the triplicate experiments.

\section{Discussion}

\subsection{Thermodynamics and Geochemical Modeling}

The $\mathrm{pH}$ cycling method, as proposed by Liebermann [17] and Deelman [16] is intended to repeatedly dissolve the metastable magnesium carbonate minerals during the acid or dissolution phase, and hence, promote the formation of the more stable magnesium carbonate minerals (dolomite and magnesite) during the base or precipitation phase of the cycles. It is well known that the inhibition of the formation of dolomite or magnesite at a low temperature is a kinetic problem and not a thermodynamic one. Nevertheless, geochemical equilibrium modeling can still provide useful information with regards to the thermodynamics, ion species distribution and saturation index of the fluids with respect to several mineral phases. The results of the calculated $\mathrm{pH}$ and saturation index using PHREEQC for the first three different stages in the two experimental series are presented in Table 1. Even though the starting $\mathrm{pH}$ of the fluids (before the addition of calcite) was significantly lower in the experimental series with zinc ions than in the control series, and that a difference in $\mathrm{pH}$ was measured for the acid phase between the control and second series of cyclic experiments, the difference in calculated $\mathrm{pH}$ between the two experimental series is smaller than 0.03. Moreover, the calculated $\mathrm{pH}$ (9.4-9.7) is much higher than the actual measured $\mathrm{pH}$ in experiments, cycling between 6.5-7.0 and 7.9-8.3 for the control series and between 5.7-6.1 and 7.9-8.4 for the series with zinc ions (Table 1). This difference is caused by the fact that the system does not reach equilibrium in the experiments, in contrast to the set thermodynamic equilibrium of the PHREEQC calculations.

Table 1. Values of $\mathrm{pH}$ and saturation index (SI) calculated using PHREEQC and the Pitzer database for geochemical equilibrium reactions at $43{ }^{\circ} \mathrm{C}$. Arag: aragonite; cal: calcite; dol: dolomite; hun: huntite; mag: magnesite.

\begin{tabular}{ccccccc}
\hline Experiment; Stage & $\mathbf{p H}$ & $\mathbf{S I}_{\text {arag }}$ & $\mathbf{S I}_{\text {cal }}$ & $\mathbf{S I}_{\mathbf{d o l}}$ & $\mathbf{S I}_{\text {hun }}$ & $\mathbf{S I}_{\text {mag }}$ \\
\hline Control; upon calcite addition & 9.697 & 3.18 & 3.41 & 7.77 & 13.34 & 3.24 \\
Control; upon acid addition & 9.442 & 3.16 & 3.39 & 7.73 & 13.28 & 3.23 \\
Control; upon base addition & 9.806 & 3.42 & 3.65 & 8.18 & 14.12 & 3.43 \\
\hline Zinc; upon calcite addition & 9.669 & 3.18 & 3.41 & 7.76 & 13.34 & 3.24 \\
Zinc; upon acid addition & 9.413 & 3.15 & 3.38 & 7.72 & 13.27 & 3.23 \\
Zinc; upon base addition & 9.783 & 3.42 & 3.65 & 8.18 & 14.13 & 3.43 \\
\hline
\end{tabular}


The calculated saturation index for aragonite, calcite, dolomite, huntite and magnesite are all higher than 1, meaning the fluid is oversaturated with respect to those minerals. Hydromagnesite and hydrozincite are not included in the Pitzer database, and the saturation index for those minerals has not been calculated. The Pitzer database was used here, though, because it is the preferred database for the modeling of highly saline solutions [21]. The results show that huntite has the highest saturation index, followed by dolomite, and then the saturation index for aragonite, calcite and magnesite are all very similar (Table 1). Despite the high oversaturation, other experiments have shown that dolomite and magnesite do not precipitate in laboratory conditions at low temperature, if $\mathrm{pH}$ cycling is not applied $[3,22]$, and if no functional surfaces $[10,11]$ or bacterial mediation [13] is used to catalyze the precipitation reactions. The results of our experiments show an evolution towards greater incorporation of $\mathrm{Mg}$ in the magnesium-rich carbonate phase in the reaction product. In the cyclic $\mathrm{pH}$ experiments with zinc ions, the relative abundance increases from very high magnesium calcite (protodolomite) $\left[\mathrm{CaMg}\left(\mathrm{CO}_{3}\right)_{2}\right]$ to huntite $\left[\mathrm{CaMg}_{3}\left(\mathrm{CO}_{3}\right)_{4}\right]$ and to magnesite $\left[\mathrm{MgCO}_{3}\right]$ with a number of cycles and time, whereas the saturation index shows an increasing trend from magnesite to dolomite to huntite. A similar evolution of increasing magnesium incorporation in the carbonate phase with an increasing number of cycles was also reported in the study by Hobbs et al. [22].

\subsection{Dissolution Rates of $\mathrm{CaCO}_{3}$ and Metastable Magnesium Carbonate Phases}

The acid or dissolution phase in the cycles of our experiments was set to one hour, which is shorter than in similar $\mathrm{pH}$ cycling experiments in previous studies [16-18,22]. Assuming an average calcite dissolution rate of about $3 \times 10^{-5} \mathrm{~mol} \mathrm{~m}^{-2} \cdot \mathrm{s}^{-1}$ based on a $\mathrm{pH}$ of about 6 or more and a temperature of $43^{\circ} \mathrm{C}[23,24]$, and a surface area of calcite of $8.72 \mathrm{~m}^{2} \cdot \mathrm{g}^{-1}$ [7], it is calculated that $0.288 \mathrm{~mol}$ calcite could be dissolved within one hour. This amount is almost 100 times larger than the amount of calcite added to the reactors at the start of the experiments $\left(0.306 \mathrm{~g}\right.$ or $\left.3.06 \times 10^{-3} \mathrm{~mol}\right)$. The dissolution rate of hydromagnesite is in the order of $10^{-9} \mathrm{~mol} \mathrm{~m}^{-2} \cdot \mathrm{s}^{-1}$ for a $\mathrm{pH}$ of 8 [25] and is expected to be higher for a $\mathrm{pH}$ of about 6 in the acid phase of the experiments. The surface area of newly formed hydromagnesite is also expected to be larger than that of calcite. Hence, one-hour dissolution phase duration is sufficient to dissolve calcium carbonate phases, and potentially also hydrated magnesium carbonate, and thus considered suitable for the purpose of the $\mathrm{pH}$ cycling strategy. Furthermore, the dissolution rate of magnesite is slower than that of dolomite [26], which may further support the increased relative abundance of magnesite in comparison with dolomite in the reaction product after many cycles, despite the higher saturation index of dolomite in comparison with magnesite.

\subsection{Magnesium Carbonate Formation}

The results of the control experiments show that the main phase being formed in the experiments contains gradually more magnesium as the number of cycles increases. The most abundant identified phase evolves from high magnesium calcite to very high magnesium calcite (or protodolomite) and to hydromagnesite, and with the percentage of magnesite increasing. Hence, no ordered dolomite was formed in the experiments. The lack of dolomite formation is consistent with the findings from $\mathrm{pH}$ cycling experiments by dos Anjos et al. [18], although those authors showed the formation of magnesite after precursors of aragonite and dypingite. Other dolomite synthesis studies (without $\mathrm{pH}$ cycling) at a temperature of less than $100{ }^{\circ} \mathrm{C}$ also indicate the formation of metastable phases such as low magnesium calcite, high magnesium calcite, very high magnesium calcite (or protodolomite), and hydrated $\mathrm{Ca}-\mathrm{Mg}$ carbonate phases $[1,27]$. In magnesite synthesis experiments at a temperature below $60{ }^{\circ} \mathrm{C}$, nesquehonite generally forms [5], then dypingite and transformation to hydromagnesite, and sometimes also brucite is formed [27]. Studies of natural, playa environments indicate that hydromagnesite probably forms by the transformation of more hydrated phases, such as lansfordite and nesquehonite, and that magnesite forms separately from pore fluids at depth and not at the expense of hydro- 
magnesite [28]. The latter study suggests magnesite is not formed by transformation of hydromagnesite at near-surface conditions in playa environments and that magnesite formation at these conditions is very slow with a rate of about $10^{-16}$ to $10^{-17} \mathrm{~mol} \mathrm{~m}^{-2} \mathrm{~s}^{-1}$ [28]. The formation of magnesite at a low temperature can be accelerated by microbial activity in natural settings [29].

The stoichiometry and ordering of dolomite and calcite follow a ripening process through dissolution and reprecipitation of metastable or intermediate phases [30,31]. Additionally, other double carbonates, such as norsethite, were shown to form through dissolution-crystallization steps to evolve from metastable to stable mineral phases, with the solvent-mediated ripening process also promoting an increase in particle size [32]. Such a ripening process is accelerated in the $\mathrm{pH}$ cycling experiments. Still, a recent study on high magnesium calcite spherulites claims that an aging process of 20 months at ambient conditions can result in the formation of magnesite nanocrystallites due to the migration of magnesium ions [33]. As highlighted in the study by Hobbs et al. [22], our results also show maximum incorporation of 90 or $92 \mathrm{~mol}^{\circ} \mathrm{MgCO}_{3}$ in the final magnesite reaction product after $36 \mathrm{pH}$ cycles in the control and zinc experiments, respectively, based on the $d_{104}$ spacing.

\subsection{Effect of Zinc Ions}

The addition of zinc ions in the saline solutions, while maintaining the ionic strength of the solution the same, causes a decrease in $\mathrm{pH}$ because $\mathrm{ZnCl}_{2}$ is a Lewis acid, meaning it can accept an electron pair from a Lewis base. The fluid starting solution has a $\mathrm{pH}$ of 6.4 in the series of experiments with zinc ions, in comparison with a $\mathrm{pH}$ of 8.6 in the control series. After the addition of calcite and the start of the $\mathrm{pH}$ cycling, the measurements show that the base phase has a similar $\mathrm{pH}$ in the control (7.9-8.3) and zinc experiments (7.9-8.4), whereas the $\mathrm{pH}$ of the acid phase is significantly lower in the zinc experiments (5.7-6.1) than in the control experiments (6.5-7.0). The reaction product assemblage and its evolution with the number of cycles is also different between the two series of experiments with a higher relative abundance of aragonite and hydromagnesite in the control experiments, in comparison to predominantly magnesite in the zinc experiments. It is interpreted that this difference in mineralogical composition in the reaction products is mainly caused by the lower $\mathrm{pH}$ conditions in the acid phase of the zinc experiments. Note that the exact same amounts of acid and base solution were added at each cycling step both in the control and zinc experimental series, and that the measured lower $\mathrm{pH}$ in the acid phase of the zinc series is thus caused by the different solution composition.

Beyond the $\mathrm{pH}$ effect caused by the presence of zinc ions, their strong hydration enthalpy can also play a role in the formation of magnesium carbonate, in particular the dehydration of magnesium ions for incorporation in the dolomite crystal structure, as suggested by Vandeginste et al. [7]. Another study showed that the addition of cobalt(II) ions in solution accelerates the formation of magnesite [34]. The latter authors interpreted this effect as a result of the incorporation of cobalt(II) in the magnesite crystal structure [34]. It is noted here that the hydration enthalpy of cobalt(II) ions $\left(-1996 \mathrm{~kJ} \cdot \mathrm{mol}^{-1}\right)$ is stronger than that of magnesium ions $\left(-1921 \mathrm{~kJ} \cdot \mathrm{mol}^{-1}\right)$, which is also the case for zinc ions and one of the underlying reasons behind the study on the effect of zinc ions. Given the link between the hydration enthalpy and impact on $\mathrm{pH}$ of the solution, it is hard to distinguish the effect of $\mathrm{pH}$ caused by the presence of background ions from the specific ion effect or hydration enthalpy on the rate of formation of magnesium carbonate. The hydration enthalpy determines how strongly water binds to the ion, which is relevant for the process of magnesium ion dehydration involved in the uptake of magnesium ions in the crystal structure of magnesite and dolomite. The specific ion effect triggers or influences physicochemical phenomena caused by the identity of the ion and not just by its concentration, charge or ionic strength. This effect was first established by Hofmeister based on the impact of inorganic salts on the solubility of protein, and can be related to the structure of water and the ion's Lewis strength. 


\section{Conclusions}

This study reported low-temperature cyclic $\mathrm{pH}$ experiments with saline solutions with and without zinc ions to test the impact on the formation of magnesium-rich carbonate. The reaction product assemblage evolves with the number of cycles, and is different for the experiments with and without zinc ions. The presence of zinc ions causes a decrease in the $\mathrm{pH}$ of the acid phase in the cyclic experiments, and favours a higher magnesite content in the reaction product assemblage after 36 cycles. In these zinc experiments, there is a clear evolution from high magnesium calcite to very high magnesium calcite (protodolomite), huntite, and then to magnesite with increasing cycle number, reflecting a ripening process towards stable carbonate phases with a higher magnesium content. In the experiments without zinc, a similar evolution can be observed, but hydromagnesite and aragonite are important phases in those experiments. Although very high magnesium calcite (protodolomite) was detected as a main magnesium-rich carbonate phase at about two weeks of diel cycles, ordered dolomite was not identified in the experiments. These findings shed light on the hypothesis of potential dolomite formation by $\mathrm{pH}$ cycling. Furthermore, these experimental results may find practical value in the context of carbon capture and storage by magnesite formation at a low temperature.

Funding: This research was funded by KU Leuven Internal Funds Bijzonder Onderzoeksfonds 2020, grant number STG/20/013.

Data Availability Statement: Data is available upon request.

Acknowledgments: The author would like to thank William Lewis and Stephen Argent for the maintenance of the XRD equipment at the School of Chemistry of the University of Nottingham.

Conflicts of Interest: The author declares no conflict of interest. The funders had no role in the design of the study; in the collection, analyses, or interpretation of data; in the writing of the manuscript, or in the decision to publish the results.

\section{References}

1. Gregg, J.M.; Bish, D.L.; Kaczmarek, S.E.; Machel, H.G. Mineralogy, nucleation and growth of dolomite in the laboratory and sedimentary environment: A review. Sedimentology 2015, 62, 1749-1769. [CrossRef]

2. Warren, J. Dolomite: Occurrence, evolution and economically important associations. Earth Sci. Rev. 2000, 52, 1-81. [CrossRef]

3. Land, L.S. Failure to Precipitate Dolomite at $25^{\circ} \mathrm{C}$ fromDilute Solution Despite 1000-Fold Oversaturation after32 Years. Aquat. Geochem. 1998, 4, 361-368. [CrossRef]

4. Saldi, G.D.; Jordan, G.; Schott, J.; Oelkers, E. Magnesite growth rates as a function of temperature and saturation state. Geochim. Cosmochim. Acta 2009, 73, 5646-5657. [CrossRef]

5. Hänchen, M.; Prigiobbe, V.; Baciocchi, R.; Mazzotti, M. Precipitation in the Mg-carbonate system-effects of temperature and $\mathrm{CO}_{2}$ pressure. Chem. Eng. Sci. 2008, 63, 1012-1028. [CrossRef]

6. Pye, C.C.; Rudolph, W.W. An ab Initio and Raman Investigation of Magnesium(II) Hydration. J. Phys. Chem. A 1998, 102, 9933-9943. [CrossRef]

7. Vandeginste, V.; Snell, O.; Hall, M.R.; Steer, E.; Vandeginste, A. Acceleration of dolomitization by zinc in saline waters. Nat. Commun. 2019, 10, 1851. [CrossRef]

8. Xu, J.; Yan, C.; Zhang, F.; Konishi, H.; Xu, H.; Teng, H.H. Testing the cation-hydration effect on the crystallization of $\mathrm{Ca}_{-\mathrm{Mg}-\mathrm{CO}_{3}}$ systems. Proc. Natl. Acad. Sci. USA 2013, 110, 17750-17755. [CrossRef]

9. Pimentel, C.; Pina, C.M. Reaction pathways towards the formation of dolomite-analogues at ambient conditions. Geochim. Cosmochim. Acta 2016, 178, 259-267. [CrossRef]

10. Roberts, J.A.; Kenward, P.A.; Fowle, D.; Goldstein, R.H.; Gonzalez, L.; Moore, D.S. Surface chemistry allows for abiotic precipitation of dolomite at low temperature. Proc. Natl. Acad. Sci. USA 2013, 110, 14540-14545. [CrossRef]

11. Power, I.M.; Kenward, P.A.; Dipple, G.M.; Raudsepp, M. Room Temperature Magnesite Precipitation. Cryst. Growth Des. 2017, 17, 5652-5659. [CrossRef]

12. Meister, P.; Reyes, C.; Beaumont, W.; Rincon, M.; Collins, L.; Berelson, W.; Stott, L.; Corsetti, F.; Nealson, K.H. Calcium and magnesium-limited dolomite precipitation at Deep Springs Lake, California. Sedimentologists 2011, 58, 1810-1830. [CrossRef]

13. Vasconcelos, C.; McKenzie, J.A.; Bernasconi, S.M.; Grujic, D.; Tiens, A.J. Microbial mediation as a possible mechanism for natural dolomite formation at low temperatures. Nat. Cell Biol. 1995, 377, 220-222. [CrossRef]

14. Pelejero, C.; Calvo, E.; Hoegh-Guldberg, O. Paleo-perspectives on ocean acidification. Trends Ecol. Evol. 2010, 25, 332-344. [CrossRef] 
15. Müller, B.; Wang, Y.; Wehrli, B. Cycling of calcite in hard water lakes of different trophic states. Limnol. Oceanogr. 2006, 51, 1678-1688. [CrossRef]

16. Deelman, J.C. Low-temperature nucleation of magnesite and dolomite. Neues Jahrb. Mineral. 1999, 7, $289-302$.

17. Liebermann, O. Synthesis of Dolomite. Nat. Cell Biol. 1967, 213, 241-245. [CrossRef]

18. Dos Anjos, A.P.A.; Sifeddine, A.; Sanders, C.J.; Patchineelam, S.R. Synthesis of magnesite at low temperature. Carbonates Evaporites 2011, 26, 213-215. [CrossRef]

19. Doebelin, N.; Kleeberg, R. Profex: A graphical user interface for the Rietveld refinement programBGMN. J. Appl. Crystallogr. 2015, 48, 1573-1580. [CrossRef]

20. Charlton, S.R.; Parkhurst, D.L. Modules based on the geochemical model PHREEQC for use in scripting and programming languages. Comput. Geosci. 2011, 37, 1653-1663. [CrossRef]

21. Bozau, E. Prozessmodellierung hochsalinarer Wässer mit einem erweiterten PHREEQC-Datensatz. Grundwasser 2013, 18, 93-98. [CrossRef]

22. Hobbs, F.W.; Xu, H. Magnesite formation through temperature and $\mathrm{pH}$ cycling as a proxy for lagoon and playa paleoenvironments. Geochim. Cosmochim. Acta 2020, 269, 101-116. [CrossRef]

23. Colombani, J. The Alkaline Dissolution Rate of Calcite. J. Phys. Chem. Lett. 2016, 7, 2376-2380. [CrossRef] [PubMed]

24. Sjöberg, E.; Rickard, D. Temperature dependence of calcite dissolution kinetics between 1 and $62{ }^{\circ} \mathrm{C}$ at pH 2.7 to 8.4 in aqueous solutions. Geochim. Cosmochim. Acta 1984, 48, 485-493. [CrossRef]

25. Berninger, U.-N.; Jordan, G.; Schott, J.; Oelkers, E.H. The experimental determination of hydromagnesite precipitation rates at 22.5-75 ${ }^{\circ}$ C. Miner. Mag. 2014, 78, 1405-1416. [CrossRef]

26. Pokrovsky, O.S.; Golubev, S.V.; Schott, J.; Castillo, A. Calcite, dolomite and magnesite dissolution kinetics in aqueous solutions at acid to circumneutral $\mathrm{pH}, 25$ to $150^{\circ} \mathrm{C}$ and 1 to $55 \mathrm{~atm} \mathrm{pCO}_{2}: \mathrm{New}$ constraints on $\mathrm{CO}_{2}$ sequestration in sedimentary basins. Chem. Geol. 2009, 265, 20-32. [CrossRef]

27. Montes-Hernandez, G.; Findling, N.; Renard, F. Dissolution-precipitation reactions controlling fast formation of dolomite under hydrothermal conditions. Appl. Geochem. 2016, 73, 169-177. [CrossRef]

28. Power, I.M.; Harrison, A.L.; Dipple, G.M.; Wilson, S.A.; Barker, S.L.; Fallon, S.J. Magnesite formation in playa environments near Atlin, British Columbia, Canada. Geochim. Cosmochim. Acta 2019, 255, 1-24. [CrossRef]

29. Montero, M.E.S.; Rodríguez-Aranda, J. Magnesite formation by microbial activity: Evidence from a Miocene hypersaline lake. Sediment. Geol. 2012, 263-264, 6-15. [CrossRef]

30. Kell-Duivestein, I.J.; Baldermann, A.; Mavromatis, V.; Dietzel, M. Controls of temperature, alkalinity and calcium carbonate reactant on the evolution of dolomite and magnesite stoichiometry and dolomite cation ordering degree-An experimental approach. Chem. Geol. 2019, 529, 119292. [CrossRef]

31. Pina, C.M.; Pimentel, C.; Crespo, Á. Dolomite cation order in the geological record. Chem. Geol. 2020, 547, 119667. [CrossRef]

32. Pimentel, C.; Pina, C.M. The formation of the dolomite-analogue norsethite: Reaction pathway and cation ordering. Geochim. Cosmochim. Acta 2014, 142, 217-223. [CrossRef]

33. Tsao, C.; Yu, P.-T.; Wang, C.-C.; Chan, J.C.C. Formation of nano-magnesite in the calcareous spicules prepared under ambient conditions. Chem. Commun. 2020, 56, 6925-6928. [CrossRef] [PubMed]

34. Felmy, A.R.; Qafoku, O.; Arey, B.W.; Kovarik, L.; Liu, J.; Perea, D.; Ilton, E.S. Enhancing magnesite formation at low temperature and high $\mathrm{CO}_{2}$ pressure: The impact of seed crystals and minor components. Chem. Geol. 2015, 395, 119-125. [CrossRef] 